\title{
Advertising of legal services: Perceptions of attorneys
}

\author{
C. Boshoff \\ Department of Business Economics. Vista University, Private Bag X613, Port Elizabeth, 6000 Republic of South Africa
}

\begin{abstract}
Professional practitioners are increasingly questioning the status quo with regard to restrictions on the advertising of professional services. It occurs against the background of devclopments such as deregulation and increased competition from non-professionals. Professional associations are largely uncertain how to address the issuc. This study is an attempt to contribute towards the debate concerning advertising in the legal profession. It reports on a survey among 1000 practising attorneys. The study found that attorneys are generally in favour of advertising their services, but believe that it should be conducted within the confines of certain specified guidelines.
\end{abstract}

Professionele verenigings is oënskynlik onseker oor hoe die vraagstuk benader behoort te word. Hierdie studie poog om 'n bydrae te maak tot dic debat oor die advertering van regsdienste. Verslag word gelewer oor 'n opname onder 1000 praktiserende prokureurs. Daar is bevind dat prokurcurs in die algemeen ten gunste van die advertering van regsdienste is, mits dit binne 'n raamwerk van gespesifeerde riglyne plaasvind.

\section{Introduction}

Restrictions on the rights of professional practioners to advertise their services have received a fair amount of attention in American courts. These restrictions have been viewed against the background of the first amendment of the U.S. constitution which states: 'Congress shall make no law... abridging the freedom of speech, or of the press ...' (Cohen, 1978: 59). Traditionally, free speech has thus been protected by law. However, information and opinion disseminated in a commercial context such as advertising was considered mercantile in origin and not subject to the same first amendment protection as other forms of expression (Cohen, 1978: 59).

This viewpoint was modified in 1975 when the U.S.A. Supreme Court ruled in Bigelow $v$. Virginia that, because speech appears in commercial form, it does not lose first amendment protection (Hite \& Bellizzi, 1986: 45). In a landmark case, Bates $v$. State Bar of Arizona, the court declared that the rule of the Arizona State Bar banning advertising of legal services violated constitutional protection of lawyers' commercial speech. The court decided that consumers had the right to receive such information (Hite \& Fraser, 1988: 95). However, it noted that its decision encompassed only price advertising of routine legal services in printed media (Smith \& Meyer, 1978: 288). Following this decision advertising restrictions have been lifted.

In South Africa restrictions on advertising by professionals are mostly still in place, but under investigation (Brice \& Philips, 1986: 80; Bobbert, 1988: 282). In certain professions advertising has been discussed openly and even encouraged. The South African Institute of Chartered Accountants, for instance, held a referendum during 1986 to establish whether accountants in public practice were in favour of the relaxation of restrictions on advertising by its members. In other professions advertising is heavily questioned and often a questionable activity (Wheatley, 1983: 23). From a legal perspective this 'anxiety' may stem from the ideal that legal counsel is provided by a profession and not a business - justice cannot be sold (Hazard, Pearce \& Stempel, 1983: 1112).

In legal circles in South Africa the issue of advertising has received some attention, but limited empirical information is available. This study investigated how practising attorneys perceive the advertising of legal services.

\section{Objectives}

The objectives of the study were to:

- establish how respondents view the possible implications of advertising for both the profession and consumers;

- indicate which aspects of advertising attorneys favour and which aspects they are opposed to;

- predict which attorneys are most likely to advertise their services given the opportunity to do so; and

- investigate the relationship between the attitude of attorneys towards advertising and certain personal and practice-related characteristics.

\section{Methodology}

Questionnaires were mailed to a systematic random sample of 1000 attorneys in private practice. The registration list of the Law Society of the Cape of Good Hope served as sampling frame. A response rate of $35,6 \%$ was achieved, after one mail follow-up.

The questionnaire consisted of 72 statements linked to a five-point Likert-type scale on which respondents could indicate their agreement or disagreement with each statement. The scales ranged from strongly agree (value 5) to strongly disagree (value 1). The statements covered the issues on which the debate of the possible advertising of legal services centres.

Table 1 indicates the composition of the respondent group.

\section{Non-response bias}

An attempt was made to estimate non-response bias by means of extrapolation. Time trends were used, where it is assumed that those responding late are more similar to 
Table 1 Composition of respondent group

Personal and practice-

related characteristics

Age
$20-29$
$30-39$
$40-49$
$50-59$
$60+$
Experience in practising of law (years)
$0-9$
$10-19$
$20-29$
$30-39$
$40+$

Language medium of university attended

Predominantly English speaking

Predominantly Afrikaans speaking

Double medium

Other

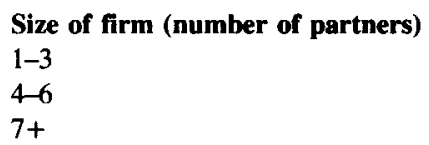

Position in firm

Senior partner

Partner

Junior partner

Professional assistant

Predominant market served

Mainly private individuals

Mainly business and other organizations

Mainly private individuals but also

business and other organizations

Mainly business and other organizations

but also private individuals

An equal proportion of business and other organizations, and private individuals

Location of main branch

Rural area

Central business area of major city

Outlying areas of major city

Number of branches

$1-2$

$3-4$

$5+$

Length of association

with present firm (years)

$0-5$

$6-10$

$11-15$

$16-20$

$21+$
Number $\%$ of total

\begin{tabular}{rrr}
30 & 8,4 \\
152 & & 42,7 \\
86 & & 24,2 \\
57 & & 16,0 \\
31 & & 8,7 \\
356 & & 100,0 \\
139 & & 39,0 \\
100 & & 28,1 \\
58 & & 16,3 \\
47 & & 13,2 \\
12 & & 3,4 \\
356 & & 100,0 \\
& & \\
132 & & 37,1 \\
131 & & 36,8 \\
75 & & 21,1 \\
18 & & 5,1 \\
\hline 356 & & 100,1
\end{tabular}

\begin{tabular}{rrr}
181 & 50,8 \\
87 & 24,5 \\
88 & & 24,7 \\
\cline { 1 - 1 } 356 & & 100,0
\end{tabular}

$\begin{array}{rrr}151 & & 42,4 \\ 131 & & 36,8 \\ 23 & & 6,5 \\ 51 & & 14,3 \\ 356 & & 100,0\end{array}$

\begin{tabular}{rrr}
35 & 9,8 \\
7 & 2,0 \\
115 & 32,3 \\
79 & 22,2 \\
120 & & 33,7 \\
\hline 356 & & $\frac{100,0}{}$
\end{tabular}

$\begin{array}{rrr}117 & & 32,9 \\ 189 & & 53,1 \\ 50 & & 14,0 \\ 356 & & 100,0\end{array}$

\begin{tabular}{rcc}
316 & & 88,8 \\
40 & & 11,2 \\
0 & & 0 \\
\cline { 1 - 1 } 356 & & 100,0
\end{tabular}

\begin{tabular}{rrrr}
136 & & 38,2 \\
82 & & 23,0 \\
33 & & 9,3 \\
32 & & 9,0 \\
73 & & 20,5 \\
\cline { 1 - 1 } \cline { 1 - 1 } 356 & & 100,0
\end{tabular}

Due to rounding off, some percentages may not add up to exactiy 100 non-respondents (Armstrong \& Overton, 1977: 397). Table 2 shows a comparison between the first quartile of respondents (89) and the last quartile (89). Accepting a minimum requirement of four degrees of freedom and a maximum of $20 \%$ cells with an expected frequency less than five, the following variables were used for this comparison: age, experience in the practising of law, length of period associated with present firm, and nature of market served.

The chi-square analysis performed shows that the nature of the market served is the only personal and practice-related variable according to which the first quartile differ significantly from the last quartile suggesting that non-response bias was negligible.

Owing to the influence of the size of the firm on the findings of previous similar studies the minimum requirement of four degrees of freedom was relaxed (which weakens the Chi-square test) to establish whether the above conclusion also applied to this variable.

While this limitation is kept in mind, the first and last quartiles of respondents do not differ significantly in terms of the size of firms as measured by the number of partners involved $\left(\chi^{2}=2,421 ; D . f .=2 ;\right.$ significance $=$ 0,298 ).

\section{The issues}

The debate on the possible advertising of legal services has centred on a number of important issues. These include:

- the possible impact and implications of advertising on the profession and consumers;

- practical considerations such as the information content of advertising, appropriate media, responsibility for placing advertisements; and

- regulatory aspects.

The question whether the advertising of legal services serves any purpose is discussed against the background of the role of traditional information sources used by consumers before an attorney is selected. These include reputation and personal information sources such as friends and relatives.

The potential implications of advertising on the legal profession and consumers

The potential impact and implications of the advertising of professional services mentioned most frequently in the marketing literature (Bloom, 1977; Shimp \& Dyer, 1978; Smith \& Meyer, 1978; Hite \& Bellizzi, 1986; Smith \& Meyer, 1980; Hazard, Pearce \& Stempel, 1983; Hite \& Fraser, 1988) and which are applicable to the legal profession, are the following:

The advertising of legal services may:

- create new job opportunities;

- establish, modify, or reinforce the image of a legal firm;

- correct mistaken beliefs about the performance or reliability of a legal firm;

- encourage contact with or trial of an previously untried legal service;

- enhance the reputation of the firm or profession; 
Table 2 Profile of first and last quartiles of respondents

\begin{tabular}{|c|c|c|}
\hline & First quartile & Last quartile \\
\hline \multicolumn{3}{|l|}{ Age of respondents" } \\
\hline $20-29$ & 6 & 9 \\
\hline $30-39$ & 43 & 41 \\
\hline $40-49$ & 19 & 20 \\
\hline $50-59$ & 11 & 10 \\
\hline \multirow[t]{2}{*}{$60+$} & 10 & 9 \\
\hline & $\overline{89}$ & $\overline{89}$ \\
\hline \multicolumn{3}{|l|}{$\begin{array}{l}\text { Experience in practising of } \\
\text { law (years) }\end{array}$} \\
\hline $0-9$ & 31 & 38 \\
\hline $10-19$ & 30 & 25 \\
\hline $20-29$ & 15 & 15 \\
\hline $30-39$ & 11 & 7 \\
\hline \multirow[t]{2}{*}{$40+$} & 2 & 4 \\
\hline & $\overline{89}$ & $\overline{89}$ \\
\hline \multicolumn{3}{|l|}{$\begin{array}{l}\text { Length of association with } \\
\text { present firm (years) }\end{array}$} \\
\hline $0-5$ & 27 & 40 \\
\hline $6-10$ & 27 & 19 \\
\hline $11-15$ & 9 & 7 \\
\hline $16-20$ & 9 & 8 \\
\hline \multirow[t]{2}{*}{$21+$} & 17 & 15 \\
\hline & $\overline{89}$ & $\overline{89}$ \\
\hline \multicolumn{3}{|l|}{ Nature of market served ${ }^{d}$} \\
\hline Private individuals & 7 & 11 \\
\hline Business/other organizations & 1 & 2 \\
\hline \multicolumn{3}{|l|}{$\begin{array}{l}\text { Mainly private individuals, } \\
\text { also business/other organi- }\end{array}$} \\
\hline zations & 24 & 34 \\
\hline \multicolumn{3}{|l|}{ Mainly business/other } \\
\hline individuals & 29 & 12 \\
\hline \multicolumn{3}{|l|}{$\begin{array}{l}\text { Equal proportion business/ } \\
\text { other organizations and pri- }\end{array}$} \\
\hline \multirow[t]{3}{*}{ vate individuals } & 28 & 30 \\
\hline & 一 & - \\
\hline & 89 & 89 \\
\hline
\end{tabular}

${ }^{a} \chi^{2}=0,774 ;$ d.f. $=4$; significance $=0,942$. No significant difference between first and last quartiles of respondents

${ }^{b} x^{2}=2,720 ;$ d.f. $=4$; significance $=0.606$. No significant difference between the first and last quartiles of respondents.

${ }^{c} \chi^{2}=4,348 ;$ d.f. $=4 ;$ significance $=0,361$. No significant difference between the first and last quartiles of respondents

${ }^{d} \chi^{2}=10.064 ;$ d.f. $=4$; significance $=0.039$. Significant difference between first quartile and last quartile of respondents

- allow consumers to make optimal attorney selection decisions;

- ensure increased or at least maintain competition (prevention of advertising limits competition to the detriment of the public);

- decrease prices/fees;
- enhance the quality of legal services;

- heighten the public's understanding of situations where legal assistance is required;

- allow consumers to choose a specialist for a particular legal problem/situation;

- intensify client satisfaction after service delivery;

- create an awareness of the services offered by attorneys:

- allow attorneys to specialize;

- impair the personal nature of the client-attorney relationship;

- benefit only the incompetent attorney;

- erode public confidence in the legal profession;

- not be seen as credible information by consumers;

- expose attorneys to entrepreneurial risk;

- lead to less co-operation among attorneys on matters of common interest;

- lead to a loss of clients if poorly executed;

- have a harmful influence on the dignity of the profession;

- create client dissatisfaction due to artificially inflated expectations;

- degenerate into a circus of misleading and deceptive advertising;

- be of little value as the information provided will be biased;

- be of little value as consumers will still rely on reputation and personal information sources;

- decrease competition as only large firms will be able to afford it;

- confuse rather than enlighten consumers;

- result in price collusion among attorneys if prices/fees are listed in advertisements to the detriment of the small practitioner and thus competition;

- lead to competitive pressures, which may result in dishonest and/or unethical behaviour among attorneys;

- result in higher fees for the client;

- be wasteful and unnecessary.

\section{Practical considerations}

With regard to the information content of advertising Shimp \& Dyer (1978: 76) suggested that the possibilities range from general information (name, address, phone number, hours) to complete advertising, including area of specialization, qualifications, and fee schedules. Smith \& Meyer (1978: 289), in an empirical study, investigated additional aspects, including amount of experience, law school attended, awards received, endorsements from past clients, and past court performance record.

In discussing the appropriateness of various media for legal service advertising, Shimp \& Dyer (1978: 76) mentioned newspapers, the Yellow Pages, law directories, radio and television. Hite \& Fraser (1988: 95 ) in a meta-analysis of previous research added consumers magazines, direct mail, outdoor boards, and telephone, while Smith \& Meyer (1978: 289) added brochures in office.

The question of who should be responsible for the 
placing of advertisements offers three possibilities, namely professional associations, individual firms/ attorneys (Shimp \& Dyer (1987: 76), or commercial advertising agencies.

\section{Regulatory aspects}

The regulatory aspects receiving attention in the marketing literature concern mainly the degree (if any) of regulation and the possible cost thereof.

These issues were all included in the questionnaire which served as measuring instrument in this study.

\section{Empirical findings}

\section{Frequency distributions}

The most important possible implications of advertising for the legal profession and consumers, as identified by respondents, are summarized in Table 3 . It reveals a fairly positive attitude towards the possible advertising of legal services as the majority of the potential implications can be described as advantageous to the profession, the public, or both. Respondents seem to feel that there is a need among the public for additional information about attorneys and the services they offer and that advertising is an appropriate means of satisfying the need. An interesting point is that, despite the overall positive inclination towards advertising, the majority of respondents seem to feel that a favourable reputation is still likely to ensure that the consumer chooses the best attorney.

According to Table 4 respondents believe that if the advertising of legal services is permitted, attorneys should be allowed to exercise this right only within the constraints of certain guidelines ${ }^{2}$. Apparently restrictions should be placed on the contents of advertisements, and on the advertising media which may be used, as well as on who may accept responsibility for the placement of advertisements.

Respondents feel that if advertising is permitted they should be allowed to supply the following information: - general information, for example name, address, telephone number;

- the particular legal areas in wich the firm specializes;

- how long the firm has been established; and

- the qualifications of staff/personnel.

Testimonials by clients and fee schedules appear to be inappropriate.

With regard to advertising media, law journals, the Yellow Pages, pamphlets, and newspapers appear to be appropriate but billboards seem to be unacceptable.

The responsibility for the placement of advertisements seems to lie with the law societies or individual firms.

\section{Attitude towards advertising}

To establish whether common factors existed within the original data set, a principal factor analysis was performed on the sample correlation matrix of the original 72 statements. The computer program BMDP4M (Frane, Jennrich \& Sampson, 1985) was used, by specifying a Direct Quartimin oblique rotation of the original factor matrix (Jennrich \& Sampson, 1966).
Table 3 Potential implications of advertising ${ }^{a}$

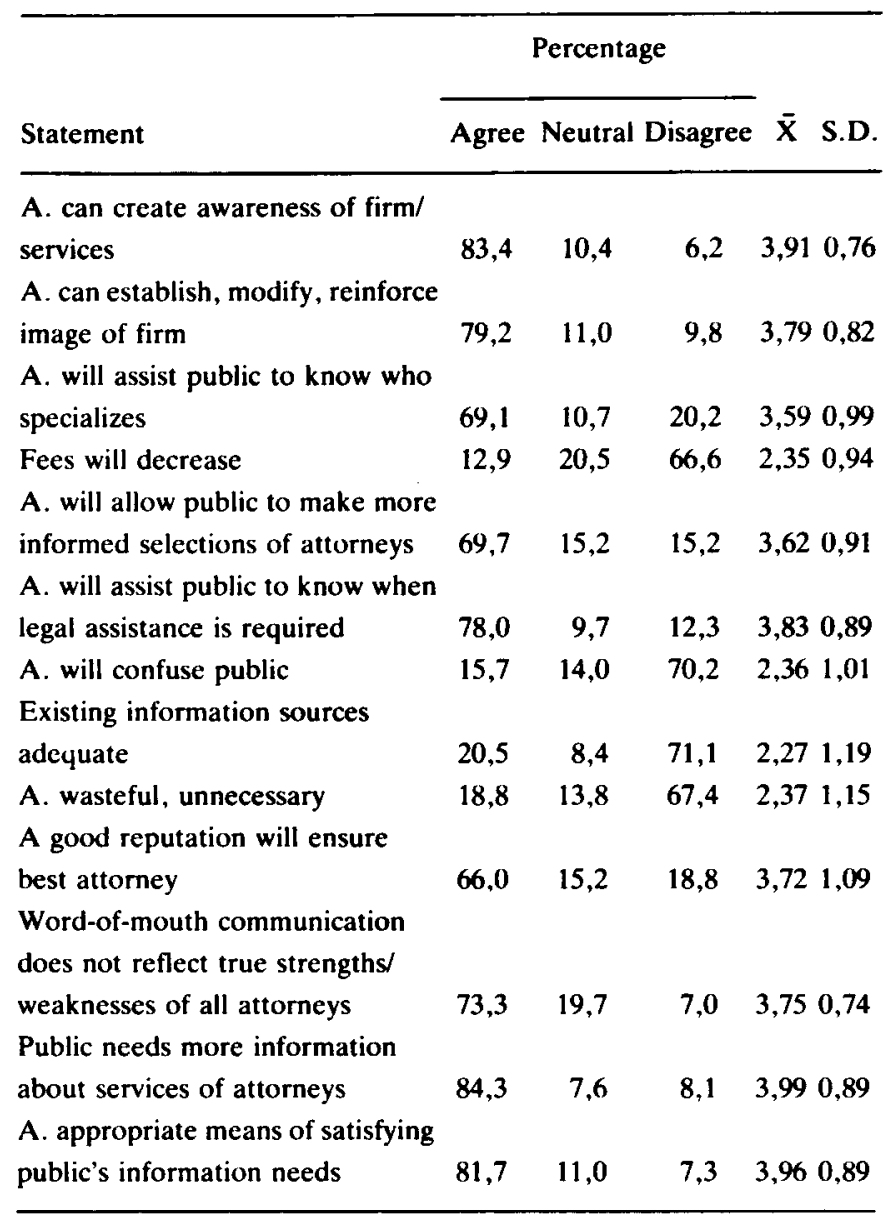

a In this table advertising is abbreviated to $\mathrm{A}$.

Keep in mind that agreement with each statement could be rated on a five-point scale, but has been collapsed to a three-point scale to facilitate easier reporting of results. Also keep in mind that some statements were negatively phrased. Only statements with a minimum of $65 \%$ agreement/disagreement are included.

The application of this program leads to the rotated factor matrix shown in Table 5 , identifying six common factors. Of these, factor 1 explains $68,2 \%$ of the variation. Only this primary common factor, measured by 21 of the original statements, is considered for further analysis.

Factor 1 appears to measure the perceptions of attorneys with regard to the general effect and implications of advertising for the legal profession and the public, and consists of the following variables:

34 - advertising will create client dissatisfaction due to artificially inflated expectations;

22 - if advertising is permitted, it will eventually degenerate into misleading and deceptive advertising;

33 - competitive pressure due to advertising will result in dishonest and unethical behaviour;

13 - advertising will harm the dignity of the profession among attorneys themselves;

37 - advertising will be expensive and the client will have to pay for it in the end; 
19 - public confidence in the legal profession will be harmed by advertising;

30 - advertising will harm the dignity of the profession among the public;

35 - advertising will limit co-operation among attorneys on matters of common interest such as legal research;

27 - the public will not regard the information provided by advertisements as credible;

12 - if advertising is permitted, the large firms will become larger still as only they can afford it and the smaller firms will be even less competitive;

25 - advertising will confuse the public;

\section{Table 4 Practical/regulatory considerations ${ }^{a}$}

\begin{tabular}{|c|c|c|c|c|}
\hline \multirow[b]{2}{*}{ Statement } & \multicolumn{3}{|c|}{ Percentage } & \multirow[b]{2}{*}{$\overline{\mathbf{X}}$ S.D. } \\
\hline & Agree & Neutral & Disagree & \\
\hline \multicolumn{5}{|l|}{ General } \\
\hline \multicolumn{5}{|c|}{ Only A.within general guide- } \\
\hline lines should be permitted & 78,9 & 8,7 & 12,4 & $3,921,02$ \\
\hline \multicolumn{5}{|l|}{ No restrictions should be } \\
\hline \multicolumn{5}{|l|}{ placed on contents of } \\
\hline advertisements & 11,0 & 4,8 & 84,3 & $1,861,08$ \\
\hline \multicolumn{5}{|l|}{ No restrictions should be } \\
\hline \multicolumn{5}{|c|}{ placed on which media may be } \\
\hline used & 16,0 & 10,1 & 73,9 & $2,171,15$ \\
\hline \multicolumn{5}{|l|}{ No restrictions should be } \\
\hline \multicolumn{5}{|l|}{ placed on who may place } \\
\hline advertisements & 14,6 & 9,6 & 75,8 & $2,101,12$ \\
\hline \multicolumn{5}{|l|}{ Advertising content } \\
\hline \multicolumn{4}{|l|}{ The following should be } & \\
\hline \multicolumn{5}{|l|}{ General information (name } \\
\hline address,tel.no., hours) & 96,9 & 1,7 & 1,4 & $4,330,62$ \\
\hline Testimonials & 12,6 & 12,6 & 74,8 & $2,061,08$ \\
\hline Prices/fees & 25,0 & 10,4 & 64,6 & $2,371,24$ \\
\hline Period established & 76,1 & 10,1 & 13,8 & $3,771,02$ \\
\hline Areas of specialization & 87,6 & 4,5 & 7,9 & $4,060,89$ \\
\hline Qualifications of staff & 73,3 & 10,4 & 16,3 & $3,731,11$ \\
\hline \multicolumn{5}{|l|}{ Advertising media } \\
\hline \multicolumn{5}{|l|}{$\begin{array}{l}\text { The following should be } \\
\text { permissible: }\end{array}$} \\
\hline Newspapers & 82,3 & 4,5 & 13,2 & $3,851,06$ \\
\hline Pamphlets & 84,6 & 4,2 & 11,2 & $2,961,35$ \\
\hline Law journals & 92,7 & 4,2 & 3,1 & $4,180,71$ \\
\hline Yellow Pages & 86,5 & 4,8 & 8,7 & $4,010,92$ \\
\hline Billboards & 9,8 & 9,3 & 80,9 & $1,921,04$ \\
\hline \multicolumn{5}{|l|}{ Placing of advertisements } \\
\hline \multicolumn{5}{|l|}{$\begin{array}{l}\text { The following should be } \\
\text { permissible: }\end{array}$} \\
\hline Individual firms & 59,8 & 12,9 & 27,3 & $3,331,20$ \\
\hline Law societies & 65,5 & 13,8 & 20,8 & $3,681,21$ \\
\hline \multicolumn{5}{|l|}{ Commercial advertising } \\
\hline agencies & 28,7 & 18,3 & 53,1 & $2,561,22$ \\
\hline
\end{tabular}

anly statements with a minimum of $65 \%$ agreement/disagreement are included
10 - information provided by advertising will be biased and thus of little value to the public;

63 - the public will still use reputation and word-ofmouth sources to select an attorney;

68 - the advertising of legal services is unethical;

8 - no advertising should be permitted;

67 - if advertising is permitted, my firm will advertise;

60 - advertising will enhance the reputation of the profession among the public;

5 - advertising will be wasteful and unnecessary;

2 - existing information sources available to the public are adequate;

1 - the attorney/client relationship is personal and should not be established as a result of advertising;

61 - advertising will benefit only the incompetent attorney.

To use the identified factor (implications of

Table 5 Sorted rotated factor loadings ${ }^{a}$

\begin{tabular}{|c|c|c|c|c|c|c|c|}
\hline \multirow{2}{*}{$\begin{array}{l}\text { Item } \\
\text { No. }\end{array}$} & \multicolumn{6}{|c|}{ Factor number } & \multirow{2}{*}{$\begin{array}{c}\text { Commu- } \\
\text { nalities } \\
\mathrm{h}^{2}\end{array}$} \\
\hline & 1 & 2 & 3 & 4 & 5 & 6 & \\
\hline 34 & 0,843 & 0,025 & 0,021 & $-0,066$ & $-0,057$ & 0,125 & 0,7264 \\
\hline 22 & 0,758 & $-0,060$ & $-0,093$ & $-0,067$ & $-0,074$ & 0,105 & 0,7317 \\
\hline 33 & 0,746 & 0,099 & 0,067 & $-0,107$ & 0,068 & 0,145 & 0,5613 \\
\hline 13 & 0,735 & $-0,127$ & 0,002 & $-0,056$ & 0,008 & 0,033 & 0,6637 \\
\hline 37 & 0,710 & 0,185 & $-0,044$ & 0,067 & 0,109 & $-0,075$ & 0,4660 \\
\hline 19 & 0,692 & $-0,067$ & $-0,140$ & $-0,124$ & $-0,133$ & $-0,034$ & 0,7133 \\
\hline 30 & 0,690 & $-0,097$ & $-0,189$ & $-0,116$ & $-0,077$ & 0,049 & 0,7736 \\
\hline 35 & 0,659 & $-0,024$ & 0,000 & $-0,025$ & $-0,054$ & 0,148 & 0,4757 \\
\hline 27 & 0,658 & $-0,085$ & $-0,035$ & $-0,093$ & $-0,101$ & $-0,071$ & 0,5685 \\
\hline 12 & 0,638 & 0,025 & 0,069 & 0,075 & 0,078 & 0,121 & 0,3689 \\
\hline 25 & 0,636 & $-0,066$ & $-0,247$ & $-0,133$ & $-0,188$ & 0,019 & 0,7405 \\
\hline 10 & 0,620 & 0,004 & $-0,082$ & $-0,099$ & $-0,135$ & $-0,006$ & 0,4849 \\
\hline 63 & 0,612 & $-0,134$ & 0,033 & 0,053 & 0,026 & $-0,015$ & 0,4190 \\
\hline 68 & 0,611 & $-0,251$ & $-0,060$ & $-0,105$ & $-0,075$ & $-0,015$ & 0,6704 \\
\hline 8 & 0,564 & $-0,106$ & $-0,116$ & $-0,119$ & $-0,122$ & $-0,127$ & 0,5471 \\
\hline 67 & $-0,543$ & 0,280 & 0,115 & $-0,039$ & $-0,183$ & 0,213 & 0,6426 \\
\hline 60 & $-0,543$ & 0,088 & 0,144 & 0,157 & 0,121 & 0,086 & 0,5426 \\
\hline 5 & 0,532 & $-0,037$ & $-0,232$ & $-0,117$ & $-0,071$ & $-0,232$ & 0,5964 \\
\hline 2 & 0,518 & $-0,090$ & $-0,148$ & $-0,094$ & $-0,016$ & $-0,132$ & 0,4809 \\
\hline 1 & 0,515 & $-0,117$ & $-0,075$ & $-0,126$ & 0,064 & $-0,027$ & 0,4527 \\
\hline 61 & 0,507 & $-0,084$ & $-0,158$ & $-0,020$ & 0,021 & 0,017 & 0,4128 \\
\hline 39 & 0,109 & 0,791 & $-0,094$ & $-0,035$ & $-0,032$ & 0.063 & 0,5330 \\
\hline 43 & $-0,130$ & 0,698 & 0,075 & $-0,008$ & $-0,012$ & $-0,054$ & 0,6186 \\
\hline 44 & $-0,060$ & 0,603 & 0,096 & 0,019 & $-0,101$ & -0.059 & 0,4624 \\
\hline 51 & 0,056 & 0,601 & $-0,103$ & 0,067 & 0,050 & 0,029 & 0,3447 \\
\hline 52 & $-0,104$ & 0,563 & $-0,120$ & 0,227 & $-0,039$ & $-0,023$ & 0,4547 \\
\hline 41 & 0,047 & $-0,000$ & 0,508 & 0,189 & $-0,122$ & $-0,352$ & 0,4756 \\
\hline 50 & $-0,142$ & 0,040 & $-0,078$ & 0,808 & 0,134 & 0,022 & 0,7157 \\
\hline 48 & $-0,103$ & 0,146 & $-0,078$ & 0,773 & 0,116 & 0,011 & 0,6984 \\
\hline 55 & 0,011 & 0,100 & 0,049 & 0,594 & $-0,238$ & 0,027 & 0,5087 \\
\hline 54 & $-0,028$ & $-0,084$ & 0,054 & 0,517 & $-0,212$ & 0.066 & 0,3681 \\
\hline 26 & 0,106 & $-0,069$ & 0,071 & $-0,116$ & 0,654 & $-0,039$ & 0,4708 \\
\hline 17 & $-0,080$ & 0,017 & 0,054 & $-0,087$ & 0,637 & $-0,041$ & 0,4164 \\
\hline 29 & 0,301 & 0,001 & $-0,041$ & $-0,056$ & $-0,031$ & 0,438 & 0,3001 \\
\hline
\end{tabular}

a Loadings greater than 0,5 were considered significant 
advertising on legal profession and consumers) in further statistical analysis, a total score of the 21 items measuring this factor was computed as an improved measurement of the factor itself in comparison with any single items scored. This was used as a dependent variable in a multiple regression analysis reported in Table 6 .

\section{Regression analysis}

A multiple regression analysis was conducted to investigate relationships between a set of certain personal and practice-related characteristics of respondents and their attitude towards the advertising of legal services, as measured by the total score referred to earlier. For this purpose the computer programme BMDPIR (Dixon \& Brown, 1985) was used and the corresponding results are presented in Table 6.

Table 6 reveals that:

1. those attorneys who would make use of advertising if given the opportunity to do so feel significantly more positive about the implications of advertising than those who would not advertise or those who are uncertain about their intentions;

2. the attorneys who are practising in larger firms (measured in terms of number of partners) feel significantly more positive about the implications of advertising than those pracrising in smaller firms;

3. attorneys practising in rural areas feel significantly more positive about the implications of advertising than their counterparts practising in urban areas; and 4. less experienced attorneys feel significantly more

Table 6 Results of regression analysis

\begin{tabular}{|c|c|c|}
\hline Independent variable & Coefficient & $\mathrm{P}>\mathrm{T}$ \\
\hline Age & 0,86710 & 0,4988 \\
\hline Expcrience & $-2,34695$ & $0,0543^{\circ}$ \\
\hline Number of partners & 2,64502 & $0,0122^{b}$ \\
\hline Number of branches & $-1,00112$ & 0.6275 \\
\hline Period associated with current firm & $-0,04479$ & 0,9495 \\
\hline University graduated-Fnglish & 0,31233 & 0.7643 \\
\hline University graduated-Afrikaans & 0.01397 & 0,9890 \\
\hline Senior partner & $-0,68833$ & 0,8087 \\
\hline Partner & $-1,00973$ & 0.7196 \\
\hline Junior partner & $-1,51216$ & 0.6576 \\
\hline Professional assistant & -1.02911 & 0.7408 \\
\hline Market: private individuals & 0,50904 & 0.8093 \\
\hline Market: organizations & -0.68118 & 0.8632 \\
\hline \multicolumn{3}{|l|}{ Market: mainly private individuals } \\
\hline but also organizations & $-0,19997$ & 0.8964 \\
\hline \multicolumn{3}{|l|}{ Market: mainly organizations but } \\
\hline also private individuals & 1,23207 & 0,4664 \\
\hline Located in rural arca & 1.96837 & $0.0817^{\circ}$ \\
\hline Located in urban arca & -0.33581 & 0.7565 \\
\hline Advertising intentions-yes & 15.30387 & $0,0000^{4}$ \\
\hline Advertising intentions-no & -13.03616 & $0,00000^{\mathrm{A}}$ \\
\hline
\end{tabular}

Multiple R - Square $0.4885 ;{ }^{\prime \prime} p<0,01 ;{ }^{\mathrm{b}} p<0.05 ;{ }^{\circ} p<0,10$ positive about the implications of advertising than their more experienced colleagues ${ }^{3}$.

Personal and practice-related characteristics such as age, language medium of university attended, position in the firm, type of market served, and period of association with present firm have no significant influence on the attitude of attorneys towards the advertising of their services.

\section{Conclusions}

Attorneys seem to feel fairly positive about the implications of the advertising of their services, particularly:

- those who would advertise if given the opportunity to do so;

- the more inexperienced attorneys;

- those who are practising in rural areas; and

- those who practise in the larger sized firms.

The majority $(60,7 \%)$ indicated that they would advertise if the opportunity presented itself. There is strong support, however, for the idea that the right to advertise should be exercised within the constraints of some sort of guidelines.

\section{Limitations of the study}

This study did not address the question of institutional advertising - advertising by representative bodies such as the law societies. A second limitation is that it did not investigate who should be responsible for providing the guidelines which the majority of the respondents thought should be used to regulate legal services advertising. Both these limitations - and particularly the wider regulatory issues such as the enforcement of these guidelines - leave scope for further research.

\section{Notes}

1. Only personal and practice-related variables yielding at least four degrees of freedom and with no more than $20 \%$ of cells with an expected frequency of less than five, were used for the comparison.

2. The questionnaire did not pursue the question of who should provide the guidelines.

3. Although relationships (3) and (4) are significant only at the 0,10 level, and are often not reported, they are regarded as significant in the context of the objectives of this study.

\section{References}

Armstrong, J.S. \& Overton, T.S. 1977. Estimating nonresponse bias in mail surveys. J. Market. Res., vol.xiv. August, 396402.

Bloom, P.N. 1977. Advertising in the Professions: The critical issues. J. Market., July. vol.41(3), 103-110.

Bobbert, M.C.J. 1988. 'n Vergelykende studie van die bemarking van regsdienste in verskeie lande. De Rebus, April, 277-282.

Brice, H. \& Philips. B. 1986. The deregulation of professional scrvices - a marketing challenge. S. Afr. $J$. Bus. Manage., vol.17. 79-86. 
Cohen, D. 1978. Advertising and the First Amendment. J. Market., July, 59-68.

Dixon, W.J. \& Brown, M.B. (Eds.). 1985. BMDP Statistical Software. Berkeley: University of California Press.

Frane. J., Jennrich, R.I. \& Sampson, P.F. 1985. P4M Factor Analysis. In: Dixon, W.J. \& Brown, M.B. (Eds.) BMDP Statistical Software. Berkeley: University of California Press.

Hazard, G.C. (Jr.), Pearce, R.G. \& Stempel, J.W. 1983. Why lawyers should be allowed to advertise : A market analysis of legal services. New York University Law Review, vol.58. November, 1084-1113.

Hite, R.E. \& Bellizzi. J.A. 1986. Consumers' attitudes toward accountants, lawyers and physicians with respect to advertising professional services. J. Advern. Res., June-July, 45-54.
Hite, R.E. \& Fraser, C. 1988. Meta-analyses of attitudes toward advertising by professionals. J. Market., vol.52, July, 95-105.

Jennrich, R.I. \& Sampson, P.F. 1966. Rotation for Simple Loadings. Psychometrika, vol. 31, 313-323.

Shimp, T. \& Dyer, R. 1978. How the legal profession views legal service advertising. J. Market., July, 74-81.

Smith. R.E. \& Meyer. T.S. 1978. Attorney attitudes toward professional advertising. Proceedings of the 1978 American Marketing Association's Educators' Conference entitled: Research Frontiers in Marketing: Dialogues and Directions, 288-291.

Smith, R.E. \& Meyer, T.S. 1980. Attorney advertising : A consumer perspective. J. Market., vol.44, Spring, 56-64. Wheatley. E.W. 1983. Marketing Professional Services. Englewood Cliffs, New Jersey: Prentice-Hall. 